Maintaining business relationships: Resilience through institutional work

Corresponding author: Ilkka Ojansivu Department of Management and Marketing

Faculty of Business and Economics University of Melbourne

Level 6, room 06.007, 198 Berkeley Street, The Spot

The University of Melbourne, Victoria 3010 Australia

$\mathrm{T}:+61420494070$

E: ilkka.ojansivu@unimelb.edu.au

Co-author: Jan Hermes, University of Oulu, jan.hermes@oulu.fi

Accepted for publication in the Journal of Business and Industrial Marketing

7 August 2019 


\title{
MAINTAINING BUSINESS RELATIONSHIPS: RESILIENCE THROUGH INSTITUTIONAL WORK.
}

\begin{abstract}
Business relationships are considered long-term and stable. Furthermore, over time, business relationships are expected to become and remain 'institutionalized'. The undertone is that this process is deterministic and inevitable. While we do not question the long-term nature of business relationships, we argue that the process of 'institutionalization' requires more construct clarity. Consequently, we ask the following: What is the source of resilience in business relationships, and how are these relationships maintained over time? To unravel these questions, we conducted an historical case study of a business relationship between a government buyer and a software seller extending over two decades. We found that while the network around the business relationship is crumbling and all odds are in favor of relationship dissolution, the active maintenance work of key individuals in the relationship prevented detrimental effects and resulted not only in its continuation but also an increased degree of institutionalization. We contribute to the Industrial Network approach by providing a non-deterministic approach to the typically taken-for-granted end phase of business relationships. Our findings illustrate that the process of institutionalization is manageable but requires hard work, highlighting managers as the principle vehicle of relationship maintenance.
\end{abstract}

Keywords business relationships, interaction, institutionalization, institutional work, maintenance 


\section{Introduction}

It is widely understood in the Industrial Network approach (INA) that business relationships are relatively durable and stable (Håkansson \& Snehota, 1995). A typical narrative is that business relationships are "long-term and stable, but not static" (Alajoutsijärvi et al., 2001: 99). 'Not static' implies that despite their stability, business relationships have an innate seed for change. In wellknown relationship development frameworks (e.g., Dwyer et al., 1987; Ford, 1980; Wilson, 1995), the intuitively incommensurable notions of stability and change are resolved by perceiving change as prescribed and linear driven by normative evolutionary paths and stages (Batonda \& Perry, 2003; Chou \& Zolkiewski, 2012; Claycomb \& Frankwick, 2010; Polonsky et al., 2010; Schurr et al., 2008; Zerbini \& Castaldo, 2007; Wilson, 1995). Consequently, change occurs in business relationships but in a steady and predictable manner.

Particularly, the final phase in development frameworks is often referred to as the 'institutionalized' phase, suggesting that the relationship is eventually "taken for granted" (Ford, 1980: 347). Indeed, Håkansson and Snehota (1995: 10) note the following: "While business relationships are often complex and informal, they tend to become institutionalized over time." Explicit and implicit routines, rituals, roles and rules of behavior emerge in the relationship (Holmlund, 2004; Håkansson \& Snehota, 1995), resulting in expectations that are no longer questioned by either party (Håkansson, 1982: 25). Thus, 'institutionalization' in the INA literature appears deterministic and inevitable, and most importantly, the parties in the relationship appear to no longer play an active role in its final phase.

While we do not question the long-term nature of business relationships, we maintain that the process of business relationship institutionalization is not as deterministic and inevitable as proposed. In contrast, our argument is that relationship maintenance requires active work by its parties. We draw upon insight from research investigating institutional maintenance work (e.g., Dacin et al., 2010; Lawrence \& Suddaby, 2006; Lawrence et al., 2011) to understand the mundane everyday efforts of business relationship parties to resiliently defend the relationship against external detrimental influences. Consequently, we ask the following question: What is the source of resilience in business relationships, and how are these relationships maintained over time?

Reconceptualizing the final phase of business relationships in the INA, i.e., their institutionalization, necessitates a higher degree of 'construct clarity' (Suddaby, 2010; Shepherd \& Suddaby, 2017). The underlying assumptions of business relationship institutionalization are not explicated, and respective ontological considerations have not been carefully made (Mandják \& Szántó, 2010; Raskovic, 2015). Construct clarity refers to the "degree to which ideas overlap or differ" (Suddaby, 2010: 352), enabling the accumulation of knowledge and distinction of what we already know and how new perspectives could broaden our understanding. In this study, we seek to move away from the INA's predominantly deterministic and steady ideas about business relationship institutionalization and provide an alternative, more agentic explanation for the stability during relationships' final phase. Our study contributes to business relationship research in the INA by (1) providing 
clarity regarding the concept of business relationship institutionalization and (2) proposing an effort-based resilience work view of the final phase of business relationships.

This paper is structured as follows. First, we discuss the current understanding of institutionalization in the INA literature. Then, we describe the institutional work literature and incorporate ideas related to active maintenance work into a re-conceptualization of business relationship institutionalization. Subsequently, we provide an empirical investigation of a historical case study of a business relationship between a government buyer and a software seller extending over two decades. We conclude by analyzing our case findings and proposing both managerial and theoretical implications.

\section{Institutionalization of business relationships in the INA literature}

The etymology of 'institutionalization' in the INA originates from the interaction model (Håkansson, 1982; Campbell, 1985). Håkansson (1982: 32) deliberately separated exchange episodes from relationships. The former comprises tangible exchanges (product, service, financial, information, and social), whereas the latter captures the longer-term processes of adaptations and institutionalization in the business relationship. As explained by Håkansson (1982: 18), the interaction model integrated insights from two major theories outside marketing: the 'inter-organizational' and 'new institutional' theories. We acknowledge that simultaneously with the interaction model, other research streams in the INA literature began to conceptualize business relationships with a "wider systems interdependence view of markets" (Mattsson \& Johanson, 2006: 259), leading to a cognizance of stable and socially integrating organizational patterns (Selznick, 1996). Over time, the cross-fertilization of theories increased as noted by Möller (2013: 330), who refers to the "disciplinary amalgamation" in the INA literature morphing resource dependency theory, social exchange theory, transaction cost economics, institutional studies, evolutionary economics and organizational theory. With this spread and speed, the depth has not kept pace (e.g., Mandják \& Szántó, 2010; Raskovic, 2015; Schurr, 2007). We consider the concept 'institutionalization' especially troublesome in this regard.

To consider institutionalization the petrification of business relationships, we need to elaborate upon our viewpoint of institutions. We consider the nature of institutions socially constructed and intangible (Berger \& Luckmann, 1966; Giddens, 1984). As defined by Fligstein (2001: 108), institutions are "rules and shared meanings that define social relationships, help define who occupies what position in those relationships, and guide interaction by giving actors cognitive frames or sets of meanings to interpret the behavior of others". The notion of shared meanings is central to this definition as follows: the social construction of institutions becomes partially tangible in interactions, allowing hidden meanings to surface (Collins, 2004). How we interact with other people in a business relationship is contingent on its institutional prescriptions (Meyer \& Rowan, 1977); we constantly interpret action and behave according to contextual rules, norms and cultural values. The typical mental models widely applied to business relationships include the metaphors of 'partnership', 'arm's length', 'marriage', 'Telos' and 'Conatus' (e.g., Alajoutsijärvi et al., 2001; 
Campbell, 1985; Möller \& Wilson, 1995; Ojansivu \& Medlin, 2018). Business relationships seldom commence from a clean slate as a 'tabula rasa' since most managers have experience with business relationships. These managers search for the institutional prescriptions of a 'partnership', 'arm's length' or other similar 'logics' (see Welch \& Wilkinson, 2002) of business relationships and adapt their behavior accordingly.

'Institutionalization' involves those developments in which "social processes, obligations, or actualities come to take on a rule-like status in social thought and action" (Meyer \& Rowan, 1977: 341). For example, the position of a 'Key Account Manager' (KAM) has a highly institutionalized social status with rules, roles and expectations for managing business relationships (Ojasalo, 2001). Similarly, 'relationship portfolio' refers to an institutionalized category of organizational activity that has meaning and value to key account managers (Corsaro et al., 2013). To understand how this concept has been used in the INA literature, we revisit seminal research related to business relationships in the INA literature published by Håkansson (1982) in which 'institutionalization' plays an important role in describing the final phase of business relationships. Quite telling of the times, no definition is provided other than eight sentences that discuss the process of institutionalization rather explicitly as shown in Table 1 . Based on these discussions, we deduce the prevalent theme of institutionalization, the nature of its process and its outcome.

Table 1. Excerpts from Håkansson's (1982) book illustrating the meaning of 'institutionalization'

Based on these excerpts, it is evident that 'institutionalization' is perceived as a predominantly passive and negative process. Only one excerpt (see quote eight in Table 1) describes active work towards institutionalization in the business relationship. By viewing humans as passive participants in the business relationship, one assumes a reality external to human minds (Matthyssens et al., 2013) characterized by deterministic assumptions about human nature in which humans and their experience are perceived as products of their external social environments (Burrell \& Morgan, 1979). Hence, institutionalization in business relationships is largely considered to originate from external structures. Thus, the social world is viewed as embedded surrounding human beings as a structure of recurrent patterns of social interaction that become institutionalized over time by being both reproduced and immersed in people's everyday lives and activities.

Consequently, the presumed dominance of external structures reduces human agency to reactionary behavior. Actors occupy positions in the institutional structure and enter relationships that depend on these positions (Coleman et al., 1998). Thus, agency is viewed as simply the a priori determined fulfilment of socially approved organizational templates (Greenwood \& Suddaby 2006). We disagree with this line of thinking as the only way to understand business relationship institutionalization. In contrast, we consider humans more capable of navigating business relationships to the desired direction (Medlin, 2012; Guercini et al., 2014; Rindova et al., 2009). To fully explain our argument, we proceed with a theoretical discussion related to institutional work.

\section{Institutional work in business relationships}


We define business relationships as a contextually bound institution. Similarly, as 'markets' or 'families' differ among cultures, business relationships also differ as institutions (Friedland \& Alford, 1991). For example, in the case of a government buyer, the public procurement cycle sets the expectation for the business relationships length (Keränen, 2017; Torvinen \& Ulkuniemi, 2016). Therefore, business relationships in the government context do not automatically 'become institutionalized' over time. In contrast, the longer these relationships continue after the legally mandated cycle (typically three or five years), the less they fit the institutional prescriptions (Meyer \& Rowan, 1977) of business relationships in that particular context. Extending the relationship beyond this legal cycle requires active work by the participants as the 'appropriate behavior' or 'common practice' of public procurement is questioned.

We argue that institutional work, which is defined as purposeful actions by individual and collective actors to create, maintain, disrupt or defend institutions (e.g., Lawrence et al., 2011; Maguire \& Hardy, 2009), can play an important role in understanding business relationships. Institutional work departs from other streams in institutional theory because it does not seek to identify only successful 'heroic' instances of institutional change and aims to highlight the everyday activities performed by individuals to "cope with, keep up with, shore up, tear down, tinker with, transform, or create anew" the institutional structures within which they are ingrained (Lawrence et al., 2011: 53). There has been a push to focus again on individuals in institutional theory (Barley, 2008; Goffman, 1983; Powell \& Colywas, 2008), and institutional work has been in the forefront (Lawrence et al., 2013; Lawrence et al., 2011).

Building upon seminal research by Lawrence and Suddaby (2006), Perkman and Spicer (2008) divide institutional work into the following three categories: political, cultural and technical. Political work refers to creating rules and regulations (Scott, 2008), defining who is 'in' and 'out' of the institution and creating alignment between personal interests and the interest of other actors. Cultural work refers to presenting an institution such that it appeals to a wider audience, such as by framing an institution in terms of broader values, norms and common identities (Ansell, 1997; Sahlin-Andersson, 2002; Scott, 2008). Finally, technical work involves creating frameworks prescribing certain courses of action, constructing 'mental models' and shared perspectives (Scott, 2008), and giving an institution more explicit transportable characteristics (Strang \& Meyer, 1993). Institutional maintenance (e.g., Micelotta \& Washington, 2013; Lawrence \& Suddaby, 2006; Lok $\&$ De Rond, 2013) is a specific stream of institutional work research that seeks to understand the process by which "meaning is perpetuated over time" (Dacin et al., 2010: 1393). For business relationships to persist and remain institutionalized, their meanings and norms need to be communicated, translated and enacted over time (Barley \& Tolbert, 1997). Regardless of its form, institutional work in business relationships requires 'social skill' (Fligstein, 2001), including flexibility, intuitivism and creativity in interpreting and comparing interactions with the appropriate behavior in business relationships (March \& Olsen, 1989; Holland et al., 1998).

Our argument is that when a business relationship commences, this relationship is compared to institutional prescriptions in that particular industry. The more time that passes, the more 
opportunities there are to question and override these prescriptions (Meyer \& Rowan, 1977). However, these explicit and implied routines, rituals, practices, roles and rules of behavior in business relationships do not emerge on their own, i.e., they need to be created (Smets \& Jarzabkowski, 2013; Perkmann \& Spicer, 2008). In addition, once they are created, they need to be enacted and maintained, i.e., re-created (Dacin et al., 2010; Micelotta \& Washington, 2013). Even though this seems axiomatic for scholars investigating institutional work, this logic contrasts the early interpretation in the INA literature (for example, see quote four in Table 1) in which a business relationship is assumed to start as a 'clean slate' and then begins to represent the industry codes of practice over time. We argue that the process is reverse and requires active work by the participants. Indeed, "institutionalization is best understood as a dynamic, ongoing process" (Barley \& Tolbert, 1997: 93). Creating a business relationship with a high degree of resilience (Scott, 2008) does not occur in a vacuum, in the contrary, institutionalization is relative to the institutional prescriptions in a particular industry. 'Institutionalization' implies that a business relationship is no longer compared with nor comparable to the institutional prescriptions; in contrast, the relationship has established its own rules and norms, which have been taken for granted by the buyer and seller organization. Thus, 'institutionalization' necessitates active work in the form of overriding industry-specific institutional prescriptions with local codes of conduct.

\section{Methodology}

\section{Research setting and design}

The methodological choices made in this research are guided by the objective of studying business relationship maintenance. The empirical case underpinning this research is a business relationship between a software supplier (Lightbear) and its main government customer (Fairtown). Over the years, this focal business relationship has influenced the development and adoption of digital services in the connected business network and the public sector. The other parties in the network include other government agencies sharing the same supplier (Lightbear) and providing similar services to citizens in the northern European region. This focal business relationship was selected because of its long-term nature and central role in the network, which enabled an analysis of relationship maintenance in a longitudinal and embedded setting (Ojansivu \& Medlin, 2018). The case choice was also determined by the main researcher's unique access to informants not only in the focal relationship but also within the network. The focal business relationship scrutinized here (between Lightbear and Fairtown) spans over two decades (2001-2019), demanding a longitudinal approach (Siggelkow, 2007). A qualitative historical case study with abductive reasoning (Dubois $\&$ Gadde, 2002) is used to benefit from theoretically deduced dimensions and empirical material. Such an approach is recommended when the focus of inquiry is a phenomenon that is contextually embedded (see Halinen \& Törnroos, 2005; Pettigrew, 1989). The long period of the study complicates data collection and excludes the use of multiple cases; consequently, a single case design (Yin, 2009) was chosen to inform the empirical part of the study. 
This study adopts a processual case research method (Langley, 1999; Langley et al., 2013). Thus, an informant's understanding of reality is accepted and viewed from within a research framework in which process is defined as "a sequence of individual and collective events, actions, and activities unfolding over time in a context" (Pettigrew, 1997: 338). To secure the trustworthiness, credibility and authenticity (Lincoln \& Guba, 1985) of the stories told by the informants, care has been taken to collect rich data from individuals with an understanding of different inter- and intra-organizational levels. This approach enables an in-depth understanding of how individuals influence the focal relationship, but simultaneously, the role of the researcher is enhanced as an essential part of the knowledge production process (Dyer \& Wilkins, 1991). In the case of contradictory understandings, the researcher is tasked with triangulating the empirical material and making sense of the complex and contextually embedded reality (Seale, 1999).

\section{Data collection}

To describe the relevant interactions, the main source of data was semi-structured interviews (Kumar et al., 1993; Arksey \& Knight, 1999) complemented with secondary data, including annual reports, company newsletters, minutes of meetings, documentary and archival data, confidential memos and statistics of the trade in the business relationship. These data enabled the researcher to assess the respondents' answers and triangulate the data as suggested in the literature (Denzin, 1978; Patton, 1990). Twenty interviews were conducted within the focal business relationship, and eleven interviews were conducted within the network (see Table 2).

Table 2. Interview data

To acquire longitudinal data spanning the 2001-2019 period, the interviews were conducted over the following four separate phases: fall 2005, summer 2006, spring 2012, and summer 2012 and fall 2014; a clear objective was set for each phase (see Table 3). All interviews were recorded with the permission of the interviewees and then transcribed and analyzed. In addition, the interviews were supplemented with informal discussions to make sense of the phenomenon and clarify the informants' perspectives. The informants were chosen based on their central role in the focal business relationship or connected relationships constituting the network. Many informants held senior positions in the industry (both public and private) and were party to a quality of information that enabled them to comment authoritatively regarding nationwide developments.

Table 3. Data collection process

During the first phase (Fall 2005), the opportunity to study the business relationship arose as the management of Lightbear indicated their interest in such a research endeavor. During this phase, a snowball method (Biernacki \& Waldorf, 1981) was applied, and the interviewed managers recommended the following set of informants. The collection of the secondary data was an important part of the first phase as the technological details of the supplied software and different services applied required further understanding. During the second phase (summer 2006), the insights learned during the first phase were applied while conducting multiple interviews. The third (spring 
2012) and fourth (summer 2012 and fall 2014) phases of data collection were initiated on theoretical grounds to deepen our understanding of the business relationship and network development. During the final phase of data collection (spring 2019), we collected secondary data to verify the current status of the business relationship. These data included 1) a final funding report by the Department of Finance explaining a project in which the buyer integrated its digital services with the national standards, 2) public promotional material by the seller covering the customer's website launch with their latest software platform and 3) relevant local news articles covering important staff updates in the business relationship. These documents provided needed evidence indicating that the relationship was still intact and that the resource exchange was active.

\section{Data analysis and authenticity issues}

Given the two decades of history, attention must be paid to carefully selecting the main events shaping the institutionalization of the business relationship and its maintenance (Halinen et al., 1999). Establishing the veracity of this type of research is always problematic (see Miles \& Huberman, 1984). This study applied the process of periodization to address this challenge as follows: the turning points were identified to summarize and structure the historical material into the following three chronological periods (Hollander et al., 2005): 'institutionalization of the business relationship' (2001-2005), 'crumbling network and relationship maintenance work' (2006-2010) and 'legal cementation of the business relationship' (2011-2019). We particular focused on the reasons behind the turning points. A qualitative data analysis was employed to thematize the material (see Miles \& Huberman, 1984) first according to critical events (Easton \& Lundgren, 1992; Halinen et al., 1999) and then to identify more fine-grained themes of institutional work (Perkmann \& Spicer, 2008).

Several procedures were followed to authenticate the data interpretation (Miles \& Huberman, 1984; Silverman, 1993). These procedures included reviewing past interviews in light of recent interviews, filling the gaps in the data based on recursive informal discussions with key informants and comparing the answers with secondary data. Furthermore, the various understandings were carefully and anonymously shared with other informants, exposing the differences in view to repetitive dissection. This process was important considering that a respondent's understanding is necessarily partially individual and social (Lincoln \& Guba, 1985). This study reports the case in as much detail and variety as possible to enable the readers to make their own interpretations, increase their understanding, and transfer their knowledge to other contexts (Lincoln \& Guba, 1985). The results are presented in the following section. To maintain confidentiality, the true identities of the firms and respondents have been withheld, and pseudonyms are used.

\section{A nineteen-year-long historical case study of business relationship maintenance between a government buyer and a software seller}

Institutionalization of the business relationship (2001-2005) 
The business relationship between the software supplier Lightbear and the government buyer Fairtown commenced in January 2001 when Lightbear won a competitive tendering for a software system and received a one-off license payment. Lightbear retained the proprietary rights for the software, meaning that it could be serviced and developed only under Lightbear's jurisdiction. Lightbear was a small company employing 25 people when the design part of the project began in spring 2001. Founded in the late 90s, Lightbear was known for its user interface designs and webtechnology. Regardless of the great reputation, Fairtown learned quickly that tailoring the system for its specific needs would take longer than originally anticipated by Lightbear. Indeed, the launch of the Fairtown website, which was powered by the Lightbear software platform, was delayed until 2002. Fairtown, which is a medium-sized city in Europe, was tightly connected, and it was not long before the nearby city of Georgetown acquired the Lightbear software platform by the end of 2002 , followed by the neighboring city Bristol one year later. The adoption of the Lightbear software platform accelerated in 2003 when other local entities including Fairtown University, Fairtown Polytechnic and a social enterprise called the Oasis, which specializes in tourism in the Fairtown area, also acquired the same software. The seller's project manager responsible for Fairtown's account highlighted the strong role of Fairtown as follows:

"Fairtown has been one of those customers who have greatly developed the Lightbear software platform, influencing its direction to the kind of platform it is [today]. The event calendar of Fairtown is actually the first module [developed by Lightbear] that they [Fairtown] ordered, and it is still used by them and many of our other customers." (Lightbear Project Manager, interviewed 26 June 2006)

The network broadened into a local 'think tank' meeting every second month to discuss the development of digital services and Internet communications. This informal group, which was initiated by the project manager of Fairtown, Oliver Smith, expanded quickly to include the area's largest newspaper, a bank, an insurance institution and the tax administration office. The group had strong legitimacy as Oliver was able to encourage the Town Clerk of Fairtown, Harry Williams, to become the group's chairperson. Oliver was well positioned to receive support for his initiatives from the top of the bureaucracy since Harry was a colleague and close comrade of the Mayor of Fairtown. At this time, Oliver begin to search for external support, and succeeded to acquire European Union (EU) funding for two years securing a role in a nationwide digital services program called project RED. Unfortunately, Oliver's supervisor, the head of Fairtown's communications department (COMMS), Emma Durand, refused to participate in the project. This led to a major disagreement between the two forcing Oliver to sidestep his supervisor and instead request authorization from the Town Clerk Harry Williams.

The EU funding made it possible for Fairtown to hire a team concentrating on digital services that were gaining traction in the public sector. This trend was confirmed by a survey that found the local residents eager to replace outdated face-to-face encounters with digital services. The aim of the 'think tank' was to capitalize on the Lightbear software platform and to use the Fairtown 
websites as an Internet portal integrating the digital services that the local businesses and public authorities would offer for the local residents.

Lightbear developed over twenty tailored solutions for Fairtown from which many were adopted also by other participants of the network (Ojansivu \& Medlin, 2018). This changed the nature of the business relationship towards partnership increasing Fairtown's dependency on its supplier. In essence, Fairtown's software platform was embedded to other public IT systems, such as healthcare, social services, and education, creating a tightly integrated system that could only be developed and serviced by Lightbear. This caused a challenging situation in regard to EU guidelines as commented by Oliver:

"The EU project funding mechanism requires competitive bidding, but we already had a software system from Lightbear. So, it was not self-evident that we could develop the current system and purchase the required features from Lightbear. In projects funded by the EU, everything has to be put out to tender. However, we had to face the reality that no other supplier could provide the solutions, which lead us to order from Lightbear." (Oliver Smith, interviewed 15th August 2012)

Largely due to the successful partnership, Lightbear became known as the primary innovator in public sector software platforms, and Fairtown, especially its communications department, became known as a pioneer and innovator in developing Internet communications for its citizens and planning the transitioning into digital services. Oliver became a sought-after figure in government initiatives predefining regulations and guidelines for the adoption of digital services. Oliver's relationships connected the local 'think tank' to these nationwide initiatives.

Yet, this momentum was not to last. The first setback was the retirement of the Mayor of Fairtown, followed by the Fairtown's Town Clerk and chairperson of the local 'think tank' pulling out. Then, in mid-2005, the external funding from the EU ended, and Oliver had to downsize the staff. Simultaneously, both parties began substantial organizational restructurings. The municipalities of Fairtown and Georgetown were merged and Lightbear was bought by a more prominent software company. These events led to ceasing of development activities within the partnership.

\section{Crumbling network and relationship maintenance work (2006-2010)}

Following the merger with Georgetown a new IT department (Database) commenced, and Martina Taylor was hired as its head. Fairtown founded also a business development department (Clearwater) to instigate new services for its residents. As a result of these internal restructurings, COMMS lost its jurisdiction over digital services and Emma Durand's role as the head of COMMS was limited to maintaining the website content. Yet, Database prioritized the data systems integration between Fairtown and Georgetown and did not take a role in the business relationship with Lightbear. As a consequence, Emma Durand remained in charge of the business relationship after all. 
Towards the mid-2000s new technological developments made it possible to finally launch the digital services planned in the project RED. Competition in the market had increased, and several alternative software platforms had emerged. Oliver felt that Lightbear had failed to keep up with the technological developments and could not support the digital transition. This led Oliver plan a competitive tendering for a new software platform. Yet, his superior Emma Durand did not prioritize the digital transition and the need to replace Lightbear. This made the situation challenging for Oliver who had already lost the Mayor and the Town Clerk who were his long-term supporters. Oliver then contacted the new mayor in an effort to gain support. Oliver was initially successful, and the mayor introduced his ideas to the board of directors and encouraged them to implement concrete steps for digital transition as follows:

"The lifecycle of software platforms is roughly 5-6 years, and we were at the tail end of the lifecycle in 2005. We would have had one year to plan for the transition and were doing great progress, but then, it did not [long pause], well, I would have perhaps received support from the Mayor but not from my immediate manager Emma [Durand]. As I said, we had an ongoing dialogue with the mayor about the need to develop digital services for our citizens." (Oliver Smith, interviewed 15th August 2012)

Yet, Emma Durand did not support Oliver, who now turned to the new Town Clerk as a last resource. This did not yield the needed outcome and as there was no one else to turn to, Oliver resigned. The internal politics were described by Oliver as follows:

"They tried to strip down her [Emma Durand] authority, but they failed. I remember saying to the new Town Clerk that if things don't improve, I'll leave. I proposed to her that we should move the role of digital services away from the COMM's. That was my condition. Well, the situation remained the same; so, I had to leave." (Oliver Smith, interviewed 15th August 2012)

Oliver's resignation left an immediate mark on the business relationship, in which the exchanges quickly diminished to maintenance services. At Lightbear, software developers working on the Fairtown account moved to other projects. Also, activities in the 'think tank' and in the local network deteriorated. Slowly, all activities focusing on digital services development terminated and Fairtown no longer played a role in nationwide public sector projects.

During this slow-paced time period, the government agency in charge of EU funding in the northern European region complained about Fairtown's long business relationship with Lightbear as over five years had passed from the competitive tendering. Emma Durand responded by writing a letter in which she cited the close relationships in the local network that had collectively contributed to the development of Lightbear's software platform. The government agency was satisfied with this reasoning and the business relationship prolonged. 
One year later, in late 2007, Fairtown University exposed a data security issue in Lightbear's software platform. While investigating the matter, Lightbear found only an interim solution, and therefore, it encouraged an upgrade to their latest platform. All members of the network had to accept the terms laid out by Lightbear as follows:

"As a government entity, we have quite strict guidelines for procurement. All purchases that surpass a particular threshold need to be put out for tender publicly...but then, considering Lightbear, we interpreted it [the new version] as an upgrade as the platform remains the same; only the name changes... and changing large strategic platforms every three years [as per law] is practically impossible as we just don't have the required resources." (Development Manager of Fairtown Polytechnic, interviewed 12th March 2012)

At this point the markets for digital services had matured and several alternative software platforms, such as the open source WordPress, existed. As a result, many public sector authorities switched to more nimble and affordable software platforms by the late 2000s creating unrest among Lightbear's remaining public sector customers. As an attempt to regain customer trust, Lightbear hired a distinguished local politician who was an elected member of the local government of Fairtown, Richard Jones, as a project manager. This was considered a smart move as explained by the head of communications at Fairtown University:

"He [Richard Jones] was our student and an active member in university politics and a member of the town council. He was able to create a new kind of trust in the relationship, and this was a great move by Lightbear." (Fairtown University's Head of Communications, interviewed 19th June 2012)

This strategy paid dividends and the unrest subsided. In 2008 Fairtown decided to follow the recommendation of Lightbear and upgraded to its new software platform. This decision followed from several years of tailored solutions and systems integration that were difficult to untie at this point. The project manager of Lightbear responsible for the Fairtown account elaborated upon Fairtown's dependency on the Lightbear software platform as follows:

"The more they [Fairtown] have done development work, the more dependent on the platform they become. For example, Fairtown has a town planning tool for professionals, but it is also a public Internet service for the citizens. So, if they open the platform for a public tender, they need to include this feature [town planning] in the bid and develop it from scratch with the new software provider, and this is practically a waste of money." (Lightbear Project Manager, interviewed 26 June 2006)

Not everyone, however, shared this viewpoint. Martina Taylor, the head of Database, interpreted the upgrade decision as hasty and lacking thorough investigation. She was asked to endorse the upgrade only a few weeks in her position as follows: 
"It was clear that they were rushing it [the contract]; so, I didn't have time to familiarize myself with the content, and I just had to sign it. Looking back, I should have stayed calm and requested more time to prepare. Having this long relationship with a software platform provider is very risky." (Martina Taylor, interviewed 13th June 2012)

This was the starting point for a difficult relationship between Martina Taylor and Emma Durand. Even though COMMS had formally lost its jurisdiction over digital services to Database over two years ago, the business relationship with Lightbear was still managed by Emma Durand. Martina Taylor made her viewpoint clear on several instances, but she appeared to face a 'brick wall' within Fairtown as follows:

"I brought my concern to the attention of one of the managing directors [the new Town Clerk] supervising COMMS that we have a relationship with a software supplier that has lasted for more than ten years, and we need to re-evaluate it on a formal tender basis. She agreed. Yet, Emma Durand has said that the platform will not be changed during her career; so, that's the attitude." (Martina Taylor, interviewed 13th June 2012)

The relationship between COMMS and the other central administration at Fairtown became disconnected and reserved. Martina Taylor sought to enact her formal jurisdiction over digital services, re-assigned to Database by the Mayor in 2006, and thus influence Fairtown's software procurement. However, Emma Durand denied any attempt to question the business relationship with Lightbear or her role in charge of it.

\section{Legal cementation of the business relationship (2011-2019)}

Over time, the internal turbulence at Fairtown calmed down. Lightbear selected a new management group in mid-2011, and as a consequence, its strategy shifted to digital services. Lightbear hired also a new project manager to help Richard Jones (local politician) revive the business relationship with Fairtown. It was not long before this strategy was introduced that Emma Durand became interested in the possibility to improve the current platform. In late 2013, Fairtown adopted a new interface design by Lightbear and re-launched its websites. In mid-2016, a new head for COMMS was selected, and Emma Durand stepped down for part-time retirement. Subsequently, in late 2016, Fairtown received government funding to integrate its Lightbear software platform into the national e-government service platform as a part of a new national law. In the procurement of the project, led by Martina Taylor, the following special clause was used to avoid public tender:

The Act on Public Procurement and Concession Contracts 27§: "Due to technical, artistic or exclusivity reasons, only a specific supplier can fulfil the procurement." (Final funding report 29.8.2017 by the Department of Finance). 
The specification and design of the integration were provided by Lightbear as it still retained the proprietary rights for the software platform. The project was finalized in early-2017, and Fairtown began to search for funding for the software development. Notably, the integration and required software development could only be provided by Lightbear. In mid-2019, the business relationship was still intact, and Fairtown was using Lightbear's software platform.

\section{Discussion}

The institutional prescriptions of the Fairtown-Lightbear relationship largely followed the 'common practice' in business relationships in the government domain. There was a formal tendering process according to public procurement practices. The government buyer used external EU funding to cover the costs of tailoring the software platform, developing new innovative features and planning the transition to digital services. There was a general understanding that the acquired software platform would need to be put out for a public tender according to public procurement law (e.g., Keränen, 2017; Torvinen \& Ulkuniemi, 2016). However, soon, the relationship started to move in its own direction, and common practice in government procurement was surpassed. Even though the typical 'arm's length' government approach to business relationships was overridden with a 'partnership' or even a 'marriage' mental model (Alajoutsijärvi et al., 2001), this process did not occur without active work.

The project manager of the government buyer framed the business relationship as an opportunity to innovate and create digital services in the public sector. Instead of opening the software platform for public tender periodically (as per the law), the buyer and seller commenced an intensive period of product and service development. This type of cultural work (Perkman \& Spicer, 2008) enabled the development activities to diffuse from the business relationship to neighboring cities and local businesses. Assuming a role in nationwide government networks and government initiatives aimed at the diffusion of digital services, the project manager conducted technical work (Perkman \& Spicer, 2008) prescribing similar development activities in the business relationship. After receiving EU funding and social approval by top management and local businesses, the project manager appeared unstoppable.

However, the business relationship had never been a 'one-man-show', and institutional work was conducted not only to maintain but also to disrupt the relationship (e.g., Lawrence \& Suddaby, 2006; Leblebici et al., 1991; Wicks, 2001). When it became clear to the project manager that there were alternative software platforms more capable of delivering digital services, it became his mission to open the software platform for a public tender. Behind the limelight, the head of communications (supervisor of the project manager) had been conducting political work (Perkman \& Spicer, 2008) to create her own rules with the seller and decide who is 'in' and 'out' of the inner circle in the business relationship. When the project manager became a risk to the business relationship, the head of communications gave him no real option other than resign. 
After the project manager was out of the picture, the head of communications conducted institutional maintenance work to protect the business relationship from numerous incidents threatening its continuity. This work was related to (i) the re-assignment of digital services from the communications department to the IT department by the mayor, (ii) the contract concerns of the Regional Council, (iii) the data security issue, and (iv) continuous concerns by the head of the IT department of the buyer. The head of the communications framed the seller as an irreplaceable part of the buyer (Ansell, 1997; Sahlin-Andersson, 2002). As a result, the business relationship became extremely resilient to any externally or internally detrimental influences. This institutional maintenance work (e.g., Dacin et al., 2010; Micelotta \& Washington, 2013; Lok \& De Rond, 2013) sought to perpetuate the meaning of the business relationship within the communications department and across other departments of the buyer. The partnership with the seller became a norm, and the head of the communications became its organizational embodiment. This norm of a 'partnership' (Keränen, 2017) was exceptional given that other government entities, especially small and medium sized entities, had already switched to open source software platforms, such as WordPress. It appeared that the head of the communications had made herself and the business relationship irreplaceable and inseparable parts of a myth that helped preserve the normative underpinnings of the relationship (Angus, 1993; Lawrence \& Suddaby, 2006). After eleven years of patient maintenance work, this myth became legally cemented in a funding report by the Department of Finance. Consequently, the buyer was exempt from the need to open any parts of the software platform for open tender as per public procurement law, leading the business relationship to become even firmer institutionalized.

\section{Conclusions}

The aim of this paper was to provide 'construct clarity' (Suddaby, 2010; Shepherd \& Suddaby, 2017) regarding the process of business relationship institutionalization in INA research. The typical interpretation in the INA literature is that 'institutionalization' marks the final phase of a business relationship (e.g., Ford, 1980) characterized by taken for granted and sluggish characteristics embodying the "industry codes of practice" (Ford, 1980: 342; Håkansson, 1982: 310). This interpretation of institutionalization portrays an inevitable and deterministic view of the process. In this study, we sought to provide an alternative, more agentic explanation for the stability of relationships' final phase. In fact, we regarded the process as reverse. When a business relationship is inaugurated, it is compared to the institutional prescriptions established in the industry in which it is located. Over time, the industry codes of practice can be overridden by local codes of conduct, resulting in an 'institutionalized business relationship'. Furthermore, we argued that relationship maintenance requires active work by its parties and that the literature related to institutional work (e.g., Lawrence \& Suddaby, 2006; Perkman \& Spicer, 2008) and institutional maintenance work (e.g., Dacin et al., 2010; Micelotta \& Washington, 2013; Lok \& De Rond, 2013) could provide a promising stream of research to understand this phenomenon. Consequently, we proposed the following question: What is the source of resilience in business relationships, and how are these relationships maintained over time? 
We used three chronological periods bounded by turning points (Hollander et al., 2005) to describe and analyze a nineteen-year-long historical case study of a business relationship maintained between a government buyer and a software seller (2001-2019). We found that the meaning of the business relationship communicated across parties is the main source of their resilience. For example, dependencies are inevitable in business relationships (Holmlund \& Törnroos, 1997). Therefore, how these dependencies are communicated, translated and enacted over time (Barley \& Tolbert, 1997) make them truly binding. The meanings attached to business relationships can develop into myths (Angus, 1993; Lawrence \& Suddaby, 2006) that are sustained as long as the parties in the business relationship share the myths. In this case study, the meaning attached to the business relationship was 'irreplaceability'. This particular meaning grew into a myth through consistent maintenance work and became legally cemented eleven years later. As a consequence, what was initially against the institutional prescriptions of public procurement and government business relationships became the new local code of conduct. Our findings support the need to conduct institutional work to maintain business relationships over time. We identified political, cultural and technical work (Perkman \& Spicer, 2008) conducted in the business relationship, especially on the buyer side, to keep the relationship intact, i.e., protecting the relationship from the regulatory and legal concerns of external stakeholders and internal organizational rearrangements influencing the distribution of responsibilities in the business relationship.

Interestingly, institutional work was conducted not only to maintain but also to disrupt the relationship (e.g., Lawrence \& Suddaby, 2006; Leblebici et al., 1991; Wicks, 2001). We identified both a protagonist and an antagonist in the buyer organization. This type of simultaneous work for and against an institution has only recently received attention in the institutional work literature, and according to Lawrence, Leca and Zilber (2013: 1029), "we need to attend to the experience of individuals as they engage in and are subjected to, institutional work". Our focus on the key individuals and their interactions and interpretations of the business relationship opens an alternative way to approach institutionalization through the mundane everyday activities performed in the relationship (Medlin, 2012; Goffman, 1983; Guercini et al., 2014).

Our findings are also interesting from the perspective of business relationship development frameworks, which have recently received criticism (e.g., Aaboen \& Aarikka-Stenroos, 2017; Batonda \& Perry, 2003; Corsaro \& Snehota, 2012; Hedaa, 1993; Huang \& Wilkinson, 2013; Polonsky et al., 2010; La Rocca et al., 2017). We subscribe to this criticism as our findings indicate that business relationships can remain active and grow even stronger after they have been institutionalized. We also wish to emphasize that business relationships do not 'become' institutionalized; they are institutionalized by individuals actively conducting institutional work. Meanings are the main source of resilience in business relationships. Individuals attach meanings to business relationships, share and perpetuate these meanings with other individuals through political, cultural and technical work. Individuals can become the organizational embodiment of these meanings giving them a foothold in the development and resilience of business relationships. 
For managers, these findings provide practical guidance to maintaining business relationships after complex project deliveries and over long periods. We illustrated that business relationships are an 'institution' as they are social structures with a high degree of resilience (Scott, 2008). More precisely, we defined business relationships as a contextually bound institution. Business relationships are socially constructed by the people participating in them and are historically contingent on their context, and what is considered 'appropriate behavior' or 'common practice' in business relationships results from long socialization processes (e.g., Durkheim, 1956; Fligstein, 2001). In contrast to the passive view of business relationship institutionalization portrayed in the INA literature, our longitudinal evidence points to an effort-based resilience work view of business relationships. This finding leads to the following five implications:

- Relationship development frameworks or lifecycles yield an over-deterministic picture of business relationships. Institutionalization does not inevitably lead to relationship deterioration; in contrast, relationships can become even stronger.

- Managers are the principle vehicle of relationship maintenance. Through managers' active work, the meanings attached to business relationships emerge and become enacted.

- The meanings managers attach to business relationships and the way they communicate, translate and enact these meanings with other parties is very influential on relationship development.

- Managerial self-awareness and contextual knowledge are pivotal. Managers need to interpret how to behave in a business relationship, what is the appropriate behavior with a customer or a buyer and what is the 'make or break' of a particular relationship.

- Attaching a specific meaning to the business relationship, such as 'irreplaceable', 'arm's length' or 'partnership,' can even lead to new interpretation of public procurement law and codes of practice as illustrated in this case study.

In this research we scrutinized a focal business relationship between a government buyer and a software seller extending over two decades. An interesting future research avenue would be to focus on key account managers as they conduct institutional work across multiple relationships and industries in their relationship portfolios. We do not know, for example, what kinds of meaning the software supplier of our case study used in other customer relationships, particularly beyond the government sector. We believe that business relationship research in the INA has become rather homogenous over time. Our paper is an attempt to break this trend and to re-visit ideas from the new institutional theory in a similar manner as Håkansson (1982) did almost forty years ago. We argue that also the other stages in the business relationship development could benefit from institutional work approach, which stresses the active role of individuals as they seek to influence the social world around them. 


\section{References}

Aaboen, L., \& Aarikka-Stenroos, L. (2017). Start-ups initiating business relationships: process and asymmetry. IMP Journal, 11(2), 230-250.

Alajoutsijärvi, K., Eriksson, P., \& Tikkanen, H. (2001). Dominant metaphors in the IMP network discourse: 'the network as a marriage' and 'the network as a business system'. International Business Review, 10(1), 91-107.

Angus, L. B. (1993). Masculinity and women teachers at Christian Brothers College. Organization Studies, 14(2), 235-260.

Ansell, C. K. (1997). Symbolic networks: The realignment of the French working class, 18871894. American Journal of Sociology, 103(2), 359-90.

Arksey, H., \& Knight, P. T. (1999). Interviewing for social scientists: An introductory resource with examples. Sage.

Batonda, G., \& Perry, C. (2003). Approaches to relationship development processes in inter-firm networks. European Journal of Marketing, 37(10), 1457-1484.

Barley S (2008) Coalface institutionalism. In: Greenwood R, Oliver C, Sahlin K and Suddaby R (eds), The Sage handbook of organizational institutionalism. Newbury Park, CA: SAGE Publications, pp.490-516.

Barley, S. R., \& Tolbert, P. S. (1997). Institutionalization and structuration: Studying the links between action and institution. Organization studies, 18(1), 93-117.

Batonda, G., \& Perry, C. (2003). Approaches to relationship development processes in inter-firm networks. European Journal of Marketing, 37(10), 1457-1484.

Berger, P., \& Luckmann, T. (1966). The social construction of knowledge: A treatise in the sociology of knowledge. Soho, NY: Open Road Media.

Biernacki, P., \& Waldorf, D. (1981). Snowball sampling: Problems and techniques of chain referral sampling. Sociological methods \& research, 10(2), 141-163.

Burrell, G., \& Morgan, G. (1979). Sociological paradigms and organisational analysis. London: Heinemann.

Campbell, N. C. G. (1985). An interaction approach to organizational buying behavior. Journal of Business Research, 13, 35-48.

Chou, H. H., \& Zolkiewski, J. (2012). Managing resource interaction as a means to cope with technological change. Journal of Business Research, 65(2), 188-195.

Claycomb, C., \& Frankwick, G. L. (2010). Buyers' perspectives of buyer-seller relationship development. Industrial Marketing Management, 39(2), 252-263.

Coleman, S., Brudney, J.L., \& Kellough, J. E. (1998). Bureaucracy as a representative institution: Toward a reconciliation of bureaucratic government and democratic theory. American Journal of Political Science, 42(3), 717-744.

Collins, R. 2004. Interaction ritual chains. Princeton, NJ: Princeton University Press.

Corsaro, D., \& Snehota, I. (2012). Perceptions of change in business relationships and networks. Industrial Marketing Management, 41(2), 270-286. 
Corsaro, D., Fiocca, R., Henneberg, S. C., \& Tunisini, A. (2013). A value perspective on relationship portfolios. Marketing Theory, 13(3), 275-302.

Dacin, M. T., Munir, K., \& Tracey, P. (2010). Formal dining at Cambridge colleges: Linking ritual performance and institutional maintenance. Academy of Management Journal, 53(6), 1393-1418.

Denzin, N. (1978). Sociological methods: A sourcebook (2nd ed.). NY McGraw Hill.

Dubois, A., \& Gadde, L. E. (2002). Systematic combining: an abductive approach to case research. Journal of business research, 55(7), 553-560.

Durkheim, E. (1956). Education and sociology. New York: The Free Press.

Dwyer, R. F., Schurr, P. H., \& Oh, S. (1987). Developing buyer-seller relationships. Journal of Marketing, 51(2), 11-27.

Dyer, G. J., \& Wilkins, A. (1991). Better stories, not better constructs, to generate better theory: A rejoinder to Eisenhardt. The Academy of Management Review, 16(3), 613-619.

Easton, G., \& Lundgren, A. (1992). Changes in industrial networks as flow through nodes. In B. Axelsson, \& G. Easton (Eds.). Industrial networks - A new view of reality (pp. 89-104). London: Routledge.

Fligstein, N. (2001). Social skill and the theory of fields. Sociological Theory, 19: 105-120.

Ford, D. (1980). The development of buyer-seller relationships in industrial markets. European Journal of Marketing, 14(5/6), 339-354.

Friedland, R., \& Alford, R. R., (1991). Bringing society back in: Symbols, practices and institutional contradictions. In: Powell, W.W., \& DiMaggio, P. (Eds.), The New Institutionalism in Organizational Analysis (pp. 223-62). Chicago: Chicago University Press.

Giddens, A. (1984). The constitution of society. Cambridge: Polity.

Goffman, E. (1983). The interaction order: American Sociological Association, 1982 presidential address. American sociological review, 48(1), 1-17.

Greenwood, R., \& Suddaby, R. (2006). Institutional Entrepreneurship in Mature Fields: The Big Five Accounting Firms. Academy of Management Journal, 49(1), 27-48.

Guercini, S., La Rocca, A., Runfola, A., \& Snehota, I. (2014). Interaction behaviors in business relationships and heuristics: Issues for management and research agenda. Industrial Marketing Management, 43(6), 929-937.

Halinen, A., Salmi, A., \& Havila, V. (1999). From dyadic change to changing business networks: an analytical framework. Journal of Management Studies, 36(6), 779-794.

Halinen, A., \& Törnroos, J. Å. (2005). Using case methods in the study of contemporary business networks. Journal of business research, 58(9), 1285-1297.

Hedaa, L. (1993). Distrust, uncertainties and disconfirmed expectations in supplier-customer relationships. International business review, 2(2), 191-206.

Holland, D., Lachicotte, W., Skinner, D., \& Cain, C. (1998). Agency and identity in cultural worlds. Cambridge, MA: Harvard University Press.

Hollander, S. C., Rassuli, K. M., Jones, D. B., \& Dix, L. F. (2005). Periodization in marketing history. Journal of Macromarketing, 25(1), 32-41. 
Holmlund, M. (2004). Analyzing business relationships and distinguishing different interaction levels. Industrial Marketing Management, 33(4), 279-287.

Holmlund, M., \& Törnroos, J. Å. (1997). What are relationships in business networks? Management decision, 35(4), 304-309.

Huang, Y., \& Wilkinson, I. F. (2013). The dynamics and evolution of trust in business relationships. Industrial Marketing Management, 42(3), 455-465.

Håkansson, H. (1982). International Marketing and Purchasing of Industrial Goods: An Interaction Approach. In H. Håkansson (Eds.) International Marketing and Purchasing of Industrial Products (pp. 15-24). Chichester: John Wiley and Sons.

Håkansson, H., \& Snehota, I. (1995). Developing relationships in business networks. London: International Thomson.

Keränen, O. (2017). Roles for developing public-private partnerships in centralized public procurement. Industrial Marketing Management, 62, 199-210.

Kumar, N., Stern, L. W., \& Anderson, J. C. (1993). Conducting interorganizational research using key informants. Academy of management journal, 36(6), 1633-1651.

Langley, A. N. N. (1999). Strategies for theorizing from process data. Academy of Management Review, 24(4), 691-710.

Langley, A. N. N., Smallman, C., Tsoukas, H., \& Van de Ven, A. H. (2013). Process studies of change in organization and management: Unveiling temporality, activity, and flow. Academy of Management Journal, 56(1), 1-13.

La Rocca, A., Hoholm, T., \& Mørk, B. E. (2017). Practice theory and the study of interaction in business relationships: Some methodological implications. Industrial Marketing Management, 60, 187-195.

Lawrence TB, Leca B and Zilber TB (2013) Institutional work: Current research, new directions and overlooked issues. Organization Studies 34: 1023-1033.

Lawrence, T.B. \& Suddaby, R. (2006). Institutions and institutional work. In S.R. Clegg, C. Hardy,T.B. Lawrence \& W. Nord (Eds), The SAGE handbook of organization studies. Thousand Oaks, CA: SAGE, 2006, pp. 215-54.

Lawrence, T., Suddaby, R., \& Leca, B. (2011). Institutional work: Refocusing institutional studies of organization. Journal of Management Inquiry, 20: 52-58.

Leblebici, H., Salancik, G. R., Copay, A., \& King, T. (1991). Institutional change and the transformation of interorganizational fields: An organizational history of the US radio broadcasting industry. Administrative science quarterly, 333-363.

Lincoln, Y. S., \& Guba, E. G. (1985). Naturalistic inquiry. Beverly Hills: Sage.

Lok, J., \& De Rond, M. (2013). On the plasticity of institutions: Containing and restoring practice breakdowns at the Cambridge University Boat Club. Academy of Management Journal, 56(1), 185-207.

Mandják, T., \& Szántó, Z. (2010). How can economic sociology help business relationship management? Journal of Business and Industrial Marketing, 25(3), 202-208. 
Maguire, S., \& Hardy, C. (2009). Discourse and deinstitutionalization: The decline of DDT. Academy of management journal, 52(1), 148-178.

March, J. G., \& Olsen, J. P. (1989). Rediscovering institutions: The organizational basis of politics. New York: Free Press.

Matthyssens, P., Vandenbempt, K., \& Van Bockhaven, W. (2013). Structural antecedents of institutional entrepreneurship in industrial networks: A critical realist explanation. Industrial Marketing Management, 42(3), 405-420.

Mattsson, L. G., \& Johanson, J. (2006). Discovering market networks. European Journal of Marketing, 40(3/4), 259-274.

Medlin, C. J. (2012). Peter Drucker's ontology: understanding business relationships and networks. Journal of Business and Industrial Marketing, 27(7), 513-520.

Meyer, J. W., \& Rowan, B. (1977). Institutionalized organizations: Formal structure as myth and ceremony. American journal of sociology, 83(2), 340-363.

Micelotta, E. R., \& Washington, M. (2013). Institutions and maintenance: The repair work of Italian professions. Organization Studies, 34(8), 1137-1170.

Miles, M. B., \& Huberman, A. M. (1984). Qualitative data analysis: A sourcebook of new methods. Sage publications.

Möller, K. (2013). Theory map of business marketing: Relationships and networks perspectives. Industrial Marketing Management, 42(3), 324-335.

Möller, K. E., \& Wilson, D. T. (1995). Business relationships-an interaction perspective. In K. E., Möller \& D. T. Wilson (Eds.) Business Marketing: An Interaction and Network Perspective (pp. 23-52). Boston/Dordrecht/London: Kluwer Academic Publishers.

Ojansivu, I., \& Medlin, C. J. (2018). To whose drum are we marching? Change in business networks through a contextual logics perspective. Industrial Marketing Management, 70, $141-155$.

Ojasalo, J. (2001). Key account management at company and individual levels in business-tobusiness relationships. Journal of Business \& Industrial Marketing, 16(3), 199-220.

Patton, M. Q. (1990). Qualitative evaluation and research methods. SAGE Publications, Inc.

Perkmann, M., \& Spicer, A. (2008). How are management fashions institutionalized? The role of institutional work. Human Relations, 61(6), 811-844.

Pettigrew, A. M. (1989). Context and action in the transformation of the firm. Journal of Management Studies, 24(6), 649-670.

Pettigrew, A. M. (1997). What is a processual analysis? Scandinavian Journal of Management, 13(4), 337-348.

Polonsky, M., Gupta, S., Beldona, S., \& Hyman, M. R. (2010). Inactivity and the dynamics of relationship development: a proposed model. Journal of Strategic Marketing, 18(3), 257273.

Powell, W. W., \& Colyvas, J. A. (2008). Microfoundations of institutional theory. In R. Greenwood, C. Oliver, R. Suddaby, \& K. Sahlin-Andersson (Eds.). The Sage handbook of organizational institutionalism (pp. 276-298). Newbury Park, CA: SAGE Publications. 
Raskovic, M. (2015). Economic sociology and the ARA interaction model. Journal of Business and Industrial Marketing, 30(5), 472-485.

Rindova, V., Barry, D., \& Ketchen, D. J. (2009). Entrepreneuring as emancipation. Academy of Management Review, 34(3), 477-491.

Sahlin-Andersson, K. (2002). Project management as boundary work: Dilemmas of defining and delimiting. In K. Sahlin-Andersson \& A. Söderholm (Eds.), Beyond project management: New perspectives on the temporary-permanent dilemma (pp. 241-260). Copenhagen, Denmark: Liber - Copenhagen Business School Press.

Schurr, P. H. (2007). Buyer-seller relationship development episodes: theories and methods. Journal of Business and Industrial Marketing, 22(3), 161-170.

Schurr, P. H., Hedaa, L., \& Geersbro, J. (2008). Interaction episodes as engines of relationship change. Journal of Business Research, 61(8), 877-884.

Scott, W.R. (2008). Institutions and Organizations: Ideas and Interests. Thousand Oaks, CA: Sage Publications.

Seale, C. (1999). Quality in qualitative research. Qualitative Inquiry, 5(4), 465-478.

Selznick, P. (1996). Institutionalism "old" and "new". Administrative Science Quarterly, 41, 270-277.

Shepherd, D. A., \& Suddaby, R. (2017). Theory Building: A Review and Integration. Journal of Management, 43(1), 59-86.

Siggelkow, N. (2007). Persuasion with case studies. Academy of management journal, 50(1), 20 24.

Silverman, D. (1993). Interpreting qualitative data, methods for Analyzing talk, text and interaction. London: Sage Publications.

Smets, M., \& Jarzabkowski, P. (2013). Reconstructing institutional complexity in practice: A relational model of institutional work and complexity. Human Relations, 66(10), 12791309.

Strang, D., \& Meyer, J. W. (1993). Institutional conditions for diffusion. Theory and society, $22(4), 487-511$.

Suddaby, R. (2010). Editor's comments: Construct clarity in theories of management and organization. Academy of Management Review, 35(3), 346-357.

Torvinen, H., \& Ulkuniemi, P. (2016). End-user engagement within innovative public procurement practices: A case study on public-private partnership procurement. Industrial Marketing Management, 58, 58-68.

Welch, C., \& Wilkinson, I. (2002). Idea logics and network theory in business marketing. Journal of Business-to-Business Marketing, 9(3), 27-48.

Wicks, D. (2001). Institutionalized mindsets of invulnerability: Differentiated institutional fields and the antecedents of organizational crisis. Organization studies, 22(4), 659-692.

Wilson, D. T. (1995). An integrated model of buyer-seller relationships. Journal of the Academy of Marketing Science, 23(4), 335-345.

Yin, R. K. (2009). Case study research: Design and methods. Vol. 5. Sage. 
Zerbini, F., \& Castaldo, S. (2007). Stay in or get out the Janus? The maintenance of multiplex relationships between buyers and sellers. Industrial Marketing Management, 36(7), 941954. 
Tables

Table 1. Excerpts from Håkansson's (1982) book illustrating the meaning of 'institutionalization’

\begin{tabular}{|c|c|c|c|c|}
\hline \multicolumn{2}{|c|}{ Quote } & \multirow{2}{*}{\begin{tabular}{|l|} 
Theme \\
Role expectations \\
\end{tabular}} & \multirow{2}{*}{$\begin{array}{l}\text { Process } \\
\text { Passive }\end{array}$} & \multirow{2}{*}{\begin{tabular}{|l|} 
Outcome \\
Neutral
\end{tabular}} \\
\hline 1) & $\begin{array}{l}\text { "Belter's [supplier] expectation of its own and its customers role in a relationship have built up over a long period of time. This is } \\
\text { termed 'institutionalization'." (Håkansson,1982: 119) }\end{array}$ & & & \\
\hline 2) & $\begin{array}{l}\text { "Paradoxically, this reduction in uncertainty can create problems. It is possible that routine ways of dealing with the partner will } \\
\text { cease to be questioned by this stage. This can be even though these routines may no longer relate well to either party’s requirements. } \\
\text { We refer to this phenomenon as Institutionalization." (Håkansson,1982: 307) }\end{array}$ & $\begin{array}{l}\text { Mismatch between } \\
\text { routines and require- } \\
\text { ments }\end{array}$ & Neutral & Negative \\
\hline 3) & $\begin{array}{l}\text { "The effect of institutionalization on the thinking and practices of a company is also apparent in the Sprinter case where the com- } \\
\text { pany had become so 'locked' in dealings with a single supplier that it never looked beyond this relationship and accepted the associ- } \\
\text { ated poor supply performance." (Håkansson,1982: 308) }\end{array}$ & Dependency & Passive & Negative \\
\hline 4) & $\begin{array}{l}\text { "This stage [institutionalization] is reached in stable markets over long periods of time. It is marked by an extension of the institu- } \\
\text { tionalization process to a point where the conduct of business is based on industry codes of practice. These may have relatively little } \\
\text { to do with commercial considerations, but correspond more to a "right way to do business', e.g., the avoidance of price cutting and } \\
\text { restrictions on changes in the respective roles of buyer and seller." (Håkansson,1982: 310) }\end{array}$ & $\begin{array}{l}\text { Industry codes of } \\
\text { practice }\end{array}$ & Passive & Negative \\
\hline 5) & $\begin{array}{l}\text { "Any institutionalization of patterns of interaction may mean that a relationship is being operated in an inappropriate manner, either } \\
\text { because of a market or technology change, or because of the changed requirements of either company." (Håkansson,1982: 312) }\end{array}$ & Patterns of interaction & Passive & Negative \\
\hline 6) & $\begin{array}{l}\text { "Perhaps the most important lesson about the development of long-term relationships is this danger of institutionalization or habit. } \\
\text { The development of 'normal' or 'the right way' of doing things may make the organization unresponsive to market or product } \\
\text { changes in existing dealings." (Håkansson,1982: 313) }\end{array}$ & $\begin{array}{l}\text { Unresponsiveness to } \\
\text { changes }\end{array}$ & Passive & Negative \\
\hline 7) & $\begin{array}{l}\text { "Some evidence has been provided of the progressive institutionalization of personal contact patterns over time, whereby there is an } \\
\text { expectation built up of the frequency and style of contacts. Inter-company meetings become incorporated into the practices and pro- } \\
\text { cedures of the separate companies and it becomes increasingly difficult for one party to with-draw from these arrangements." } \\
\text { (Håkansson,1982: } 325 \text { ) }\end{array}$ & Routinization & Passive & Negative \\
\hline 8) & $\begin{array}{l}\text { "The 'institutionalization of the contact pattern' was also a strategy chosen by Mekanik and Motor in relation to the shipyard cus- } \\
\text { tomers..., it was the company's general strategy to try and institutionalize personal contacts in order to tie the companies closer to- } \\
\text { gether and encourage customer loyalty and a free flow of information." (Håkansson,1982: 352) }\end{array}$ & Interdependency & Active & Positive \\
\hline
\end{tabular}




\section{Table 2. Interview data}

\begin{tabular}{|c|c|c|c|c|c|}
\hline Company & Lightbear & Fairtown & Fairtown Polytechnic & Oasis & Fairtown University \\
\hline $\begin{array}{l}\text { Selection } \\
\text { criteria }\end{array}$ & $\begin{array}{l}\text { Member of } \\
\text { the seller }\end{array}$ & Member of the buyer & Member of the network & Member of the network & Member of the network \\
\hline $\begin{array}{l}\text { Sources of } \\
\text { data }\end{array}$ & $\begin{array}{l}\text { Personal interviews, } \\
\text { internal company } \\
\text { documents }\end{array}$ & $\begin{array}{l}\text { Personal interviews, } \\
\text { internal company } \\
\text { documents }\end{array}$ & $\begin{array}{l}\text { Personal interviews, } \\
\text { internal company } \\
\text { documents }\end{array}$ & $\begin{array}{l}\text { Personal interviews, } \\
\text { internal company } \\
\text { documents }\end{array}$ & $\begin{array}{l}\text { Personal interviews, } \\
\text { internal company } \\
\text { documents }\end{array}$ \\
\hline $\begin{array}{l}\text { Number of } \\
\text { informants }\end{array}$ & 12 key informants & 7 key informants & 5 key informants & 2 key informants & 2 key informants \\
\hline $\begin{array}{l}\text { Positions } \\
\text { of the key } \\
\text { informants }\end{array}$ & $\begin{array}{l}\text { Chief executive }{ }^{1} \\
\text { Sales manager }{ }^{1} \\
\text { Business unit manager }^{2} \\
\text { Leading application designer } \\
\text { Sales assistant } \\
\text { Chief project manager }^{2} \\
\text { Project manager }(\mathrm{a})^{2} \\
\text { Project manager }(\mathrm{b})^{2} \\
\text { Project manager }(\mathrm{c})^{4} \\
\text { Project manager }(\mathrm{d})^{4} \\
\text { Project manager }(\mathrm{e})^{4} \\
\text { Account manager }^{4}\end{array}$ & $\begin{array}{l}\text { Project manager }{ }^{2}\left(2^{\text {nd }} \text { interview }\right)^{4} \\
\text { Dev. unit Project } \text { Mrr }^{2} \\
\text { Head of communications }{ }^{4} \\
\text { Town Clerk } \\
\text { Data administration specialist } \\
\text { Head of IT }(a)^{4} \\
\text { Head of IT }(b)^{4}\left(2^{\text {nd }} \text { interview }\right)^{5}\end{array}$ & $\begin{array}{l}\text { Development Manager. }{ }^{2}\left(2^{\text {nd }} \text { interview }\right)^{3} \\
\text { Data administration specialist }{ }^{3} \\
\text { Head of information systems }{ }^{4} \\
\text { Information systems officer }(a)^{4} \\
\text { Information systems officer }(b)^{4}\end{array}$ & $\begin{array}{l}\text { ICT coordinator }{ }^{2} \\
w w w-\text { designer }^{2}\end{array}$ & $\begin{array}{l}\text { Head of communications }{ }^{4} \\
\text { Information systems officer }{ }^{2}\left(2^{\text {nd }}\right. \\
\text { interview })^{4}\end{array}$ \\
\hline $\begin{array}{l}\text { Duration of } \\
\text { interviews }\end{array}$ & 1-2 hours each & $1-2$ hours each & $1-2$ hours each & 1-2 hours each & $1-2$ hours each \\
\hline Total & 28 informants & 53 hours $\quad 996$ transcribed pages & & & \\
\hline
\end{tabular}


Table 3. Data collection

\begin{tabular}{|c|c|c|c|c|c|}
\hline & $\begin{array}{l}\text { Period 1: } \\
\text { Fall 2005 }\end{array}$ & $\begin{array}{l}\text { Period 2: } \\
\text { Summer 2006 }\end{array}$ & $\begin{array}{l}\text { Period 3: } \\
\text { Spring 2012 }\end{array}$ & $\begin{array}{l}\text { Period 4: } \\
\text { Summer 2012/Fall } 2014\end{array}$ & $\begin{array}{l}\text { Period 5: } \\
\text { spring 2019 }\end{array}$ \\
\hline Objective & $\begin{array}{l}\text { To understand the back- } \\
\text { ground of the case project, } \\
\text { the software project busi- } \\
\text { ness and the generic value } \\
\text { delivery of software plat- } \\
\text { forms. }\end{array}$ & $\begin{array}{l}\text { To obtain an in-depth under- } \\
\text { standing of the events shaping } \\
\text { the institutionalization of the } \\
\text { business relationship and devel- } \\
\text { opments in the network. }\end{array}$ & $\begin{array}{l}\text { To expand the longitudinal } \\
\text { perspective and obtain an } \\
\text { in-depth understanding of } \\
\text { the events shaping relation- } \\
\text { ship maintenance and de- } \\
\text { velopments in the network. }\end{array}$ & $\begin{array}{l}\text { To deepen our understanding of the } \\
\text { events shaping relationship mainte- } \\
\text { nance and the network. }\end{array}$ & $\begin{array}{l}\text { Verified the current status of the busi- } \\
\text { ness relationship. Provided evidence of } \\
\text { the current ties and resource exchange } \\
\text { between the buyer and seller. }\end{array}$ \\
\hline $\begin{array}{l}\text { Primary } \\
\text { data }\end{array}$ & $\begin{array}{l}\text { Two interviews with the } \\
\text { supplier's management. }\end{array}$ & $\begin{array}{l}\text { Eight interviews with members } \\
\text { of the business relationship and } \\
\text { six interviews with members of } \\
\text { the network. }\end{array}$ & $\begin{array}{l}\text { Two interviews with mem- } \\
\text { bers of the network. }\end{array}$ & $\begin{array}{l}\text { Ten interviews with members of the } \\
\text { business relationship and five inter- } \\
\text { views with members of the network. }\end{array}$ & \\
\hline $\begin{array}{l}\text { Secondary } \\
\text { data }\end{array}$ & $\begin{array}{l}\text { Archival data, industry re- } \\
\text { ports and newspaper arti- } \\
\text { cles. }\end{array}$ & $\begin{array}{l}\text { Archival data, industry reports } \\
\text { and newspaper articles. }\end{array}$ & $\begin{array}{l}\text { Archival data, industry re- } \\
\text { ports and newspaper arti- } \\
\text { cles. }\end{array}$ & $\begin{array}{l}\text { Archival data, industry reports, news- } \\
\text { paper articles, documents of meetings, } \\
\text { and a weblog diary of the supplier's } \\
\text { history. }\end{array}$ & $\begin{array}{l}\text { Final funding report by the Department } \\
\text { of Finance explaining a project in } \\
\text { which the buyer integrated its digital } \\
\text { services with the national standards, } \\
\text { public promotional material by the } \\
\text { seller covering the customer's website } \\
\text { launch with their latest software plat- } \\
\text { form, and relevant local news articles } \\
\text { covering important staff updates in the } \\
\text { business relationship. }\end{array}$ \\
\hline $\begin{array}{l}\text { Cumulative } \\
\text { number of } \\
\text { interviews }\end{array}$ & 2 & 14 & 16 & 32 & \\
\hline
\end{tabular}




\section{University Library}

\section{- M M N E R VA A gateway to Melbourne's research publications}

Minerva Access is the Institutional Repository of The University of Melbourne

Author/s:

Ojansivu, IT;Hermes, J

Title:

Maintaining business relationships: resilience through institutional work

Date:

2021-11-10

Citation:

Ojansivu, I. T. \& Hermes, J. (2021). Maintaining business relationships: resilience through institutional work. Journal of Business and Industrial Marketing, 36 (11), pp.2049-2061. https://doi.org/10.1108/JBIM-05-2019-0260.

Persistent Link:

http://hdl.handle.net/11343/241780 